\title{
Influence of sewage sludge composts with straw or ash on oribatid mites (Acari, Oribatida) from pine forest litter in laboratory conditions
}

\author{
ANDRZEJ KLIMEK ${ }^{1}$, BOGUSŁAW CHACHAJ ${ }^{2}$ and LESZEK KOSAKOWSKI ${ }^{1}$
}

\author{
${ }^{1}$ Division of Landscape Shaping, Department of Zoology, Kordeckiego 20, \\ University of Technology and Life Sciences, 85-225 Bydgoszcz, Poland \\ ${ }^{2}$ Department of Ecology, University of Technology and Life Sciences in Bydgoszcz, Kordeckiego 20, \\ 85-225 Bydgoszcz \\ Corresponding author: Andrzej Klimek, klimek@utp.edu.pl
}

(Received on 31 January 2008; Accepted on 15 December 2009)

\begin{abstract}
In a substrate obtained from municipal sewage sludge composts, the C:N ratio was decreased during the 12-month experiment. The amount of forest litter (layer 1 or $2 \mathrm{~cm}$ thick), used for fauna introduction, did not influence significantly the mean abundance of oribatid mites in sewage sludge compost. Oribatid mites tolerated compost alone or with straw, but were negatively influenced by addition of wood-ash. Abundance of oribatid mites in compost alone was increased from the $3^{\text {rd }}$ month, and its maximum occurred in the $10^{\text {th }}$ month. Abundance of oribatid mites in compost with straw was clearly increased since the $10^{\text {th }}-12^{\text {th }}$ month of the experiment. Generally the abundance of oribatid mites was mainly affected by Ramusella mihelcici, which was most abundant in compost alone and with straw (maximum abundance was above 100000 individuals $\mathrm{m}^{-2}$ ). However, species diversity of the mites was very low at the end of the experiment.
\end{abstract}

Keywords: sewage sludge, composts, amelioration, soil animals, bioindicators, Acari, Oribatida

\section{INTRODUCTION}

Soil animals have a great influence on soil fertility because they take part in decomposition of organic matter. A lack of soil fauna or its low biomass or species diversity, especially in forest soils, can negatively influence the soil-forming processes and functioning of whole ecosystems. This was confirmed in laboratory tests and in open areas with the use of a litterbag method (HuHTA 2007). Some soil microarthropods are closely connected with microorganisms, e.g. they can feed on ectomycorrhizal fungi (SCHNEIDER et al. 2004, 2005). Additionally, soil animals can influence the growth of fungi by grazing (HANLON \& ANDERSOn 1979, 1980). Soil fauna can also 
transport microbial propagules into fresh substrates and relocate nutrients by defecation (LuSSENHOP \& WiCKLOW 1984; LuSSENHOP 1992).

Restitution of soil fauna can be achieved by improvement of living conditions and stimulation of native populations of soil animals, as well as by introduction of new, desirable species (HAImi 2000; MAzUr \& Tracz 1996). For example, organic fertilization with composts may prove to be useful. Introduction of live soil animals on a site can be also carried out by creation of proper environmental conditions. Successful trials of introduction of soil mites were carried out in nurseries, established on forest soils and former arable land, with the use of composts produced from sewage sludge (KLIMEK et al. 2008; RoLBIECKI et al. 2007a, b).

At present, many questions connected with soil fauna inoculation are still unanswered, e.g. how sewage sludge influences the soil fauna, and what kind of structural admixtures can secure the proper development of the soil fauna. We also do not know what amount of forest litter is sufficient to give positive and durable results.

The aim of this study was to determine the influence of composts produced from municipal sewage sludge alone or with admixture of wood-ash or straw, on the abundance and species diversity of oribatid mites (Oribatida) under laboratory conditions, after inoculation of the substrate with different amounts of forest litter.

\section{MATERIAL AND METHODS}

Trials were conducted in the laboratory from August 2003 to July 2004. The experiment was established in early August 2003 in a room provided with ventilation and natural lighting. Air temperature of $18-22^{\circ} \mathrm{C}$ and relative air humidity of $65-80 \%$ were maintained during the whole experiment. Containers $(1 \mathrm{~m} \times 1.5 \mathrm{~m})$ made of chipboard were covered with plastic film in order to protect them against moisture. On the bottom of each container, a layer of pure gravel was spread ( $5 \mathrm{~cm}$ thick).

Substrate for research was prepared by the company Agromis in Lochowo near Bydgoszcz. In the experiment, the following kinds of substrate were used: digested sludge alone (variant C), digested sludge with $20 \%$ admixture of wood-ash (variant A), and digested sludge with $20 \%$ admixture of straw (variant S). Compost was produced from sewage sludge obtained from the sewage treatment plant in Żnin. Chemical analyses of substrate used in the experiment were made by Dr. Piotr Malczyk: $\mathrm{pH}$ in $1 \mathrm{M} \mathrm{KCl}$ (1:2.5) was measured using a pH meter (model CPC-551 Elmetron); organic carbon was determined by oxidizing the soil sample with a mixture of potassium dichromate and sulfuric acid, diluting the suspension with water and back titrating the excess dichromate with standardized ferrous sulfate solution (Tiurin method); total nitrogen was determined by Kjeldahl method.

Composts were uniformly spread in order to form a 5-cm-thick layer in 6 containers - treatments $\mathrm{C}, \mathrm{A}$ and $\mathrm{S}$ in 2 replications. Material for introduction was taken from the soil of a mature Scots pine forest in the Bydgoszcz Forest District. The material included the organic surface layer of the soil (forest litter) with mosses. The forest litter, immediately after transportation from forest, was spread on the composts in the containers. The layer of litter was $1 \mathrm{~cm}$ thick in treatments $\mathrm{C}_{1}, \mathrm{~A}_{1}, \mathrm{~S}_{1}$, and $2 \mathrm{~cm}$ 
thick in treatments $\mathrm{C}_{2}, \mathrm{~A}_{2}, \mathrm{~S}_{2}$. It was delicately mixed with the top layer $(2 \mathrm{~cm})$ of compost. Roughly once a week the material was sprinkled with tap water, to keep the moisture within the range $30-40 \%$.

First samples for acarological investigations were taken after initiation of the experiment (beginning of August). The next samples were taken every month to the beginning of January 2004, and since then every 2 months: in March, May, and July. The samples were $4.5 \mathrm{~cm}^{2} \times 6 \mathrm{~cm}$ deep, taken every time in 10 replications. In total, 90 samples were taken from each container. To increase the efficiency of mite extraction, every sample was divided into 2 parts. Mites were extracted from the samples for 7 days according to the Tullgren method. In total, 4377 Oribatida were examined. Mite abundance was expressed per $1 \mathrm{~m}^{2}$ of substrate, and species diversity of oribatid mites was assessed as the total number of species, the mean number of species per sample, and the Shannon index of diversity ( $H^{\prime}$ ) (MAGURRAN 1988). Significance of differences in mean abundance of oribatid mites and mean number of species was assessed by analysis of variance and the Tukey test. The data on mites were ln-transformed $(\mathrm{x}+1)$ prior to the analysis (BERTHET \& GERARD 1965).

\section{RESULTS}

At the beginning of the experiment, $\mathrm{pH}$ value was the lowest in $\mathrm{A}_{1}$ (with woodash, $1 \mathrm{~cm}$ of litter), but after the experiment its $\mathrm{pH}$ rose from 3.95 to 7.04 (Table 1). A similar increase in $\mathrm{pH}$ was noted in $\mathrm{S}$ (with straw), whereas in $\mathrm{C}$ (compost alone), an opposite trend was observed.

Table 1. Chemical properties of sewage sludge composts $(\mathrm{C}=$ compost alone, $\mathrm{A}=$ with wood-ash, $\mathrm{S}=$ with straw) mixed with 1 or $2 \mathrm{~cm}$ of leaf litter

\begin{tabular}{ccrrrrrr}
\hline \multirow{2}{*}{ Chemical property } & \multicolumn{7}{c}{ Experimental variants } \\
\cline { 3 - 8 } & & $\mathrm{C}_{1}$ & $\mathrm{C}_{2}$ & $\mathrm{~A}_{1}$ & $\mathrm{~A}_{2}$ & $\mathrm{~S}_{1}$ & $\mathrm{~S}_{2}$ \\
\cline { 3 - 8 } & initial & 4.61 & 5.43 & 3.95 & 5.20 & 4.11 & 5.64 \\
\multirow{2}{*}{$\mathrm{pH}_{\mathrm{KCl}}$} & final & 4.52 & 4.20 & 7.04 & 6.96 & 6.43 & 6.84 \\
\hline \multirow{2}{*}{ Organic C (\%) } & initial & 11.26 & 31.09 & 18.26 & 29.04 & 15.69 & 24.33 \\
& final & 8.26 & 9.14 & 7.90 & 12.36 & 11.08 & 7.69 \\
\hline \multirow{2}{*}{ Total N (\%) } & initial & 0.38 & 0.53 & 0.62 & 0.61 & 0.45 & 0.44 \\
& final & 0.52 & 0.61 & 0.40 & 0.66 & 0.43 & 0.55 \\
\hline \multirow{2}{*}{$\mathrm{C} / \mathrm{N}$} & initial & 29.60 & 58.70 & 29.50 & 47.60 & 34.90 & 55.30 \\
& final & 15.90 & 15.00 & 19.80 & 18.70 & 25.80 & 14.00 \\
\hline
\end{tabular}

Variation in organic carbon $\left(\mathrm{C}_{\text {org }}\right)$ at the beginning of the study was mostly dependent on the amount of forest litter. If its layer was $1 \mathrm{~cm}$ thick, $\mathrm{C}_{\mathrm{org}}$ ranged from 11.3 to $18.3 \%$; if $2 \mathrm{~cm}$ thick, then $\mathrm{C}_{\text {org }}$ ranged from $24.3 \%$ to $31.1 \%$. In all contain- 
ers, $\mathrm{C}_{\text {org }}$ content decreased 2-3 times during the experiment. The $\mathrm{C}: \mathrm{N}$ ratio ranged from 29.5 to 34.9 if the forest litter layer was $1 \mathrm{~cm}$ thick, and from 47.6 to 58.7 if it was $2 \mathrm{~cm}$ thick. The ratio distinctly decreased in all the treatments by the end of the experiment, and varied then from 14 to 25.8. This can be connected with a proper course of organic matter decomposition.

The abundance of oribatid mites, on average for the whole experiment, ranged from 1550 to 27120 individuals per $1 \mathrm{~m}^{2}$ (Table 2). High abundance was noted if compost alone $(\mathrm{C})$ or with straw $\left(\mathrm{S}_{1}\right)$ was used. Oribatid mites were much less abundant in compost with wood-ash (A).

Table 2. Density and species diversity of Oribatida in sewage sludge composts $(\mathrm{C}=$ compost alone, $\mathrm{A}=$ with wood-ash, $\mathrm{S}=$ with straw) mixed with 1 or $2 \mathrm{~cm}$ of leaf litter

\begin{tabular}{ccrrrrrrc}
\hline \multirow{2}{*}{ Index } & & \multicolumn{7}{c}{ Experimental variants } \\
\cline { 3 - 8 } & & \multicolumn{1}{c}{$\mathrm{C}_{1}$} & \multicolumn{1}{c}{$\mathrm{C}_{2}$} & $\mathrm{~A}_{1}$ & $\mathrm{~A}_{2}$ & $\mathrm{~S}_{1}$ & $\mathrm{~S}_{2}$ \\
\hline \multirow{2}{*}{ Mite density } & mean & 19.45 & 27.12 & $1.55^{\mathrm{A}}$ & $2.98^{\mathrm{A}}$ & 20.91 & $7.02^{\mathrm{AB}}$ \\
$\left(10^{3} / \mathrm{m}^{2}\right)$ & initial & 3.90 & 10.08 & 3.58 & 11.86 & 3.09 & 4.06 \\
& final & 9.91 & 17.71 & 0.65 & 0.33 & $105.30^{\mathrm{C}}$ & $42.09^{\mathrm{BC}}$ \\
\hline \multirow{2}{*}{ Total no. of } & overall & 14 & 16 & 13 & 20 & 18 & 18 \\
species & initial & 9 & 14 & 11 & 16 & 10 & 12 \\
& final & 1 & 5 & 1 & 2 & 4 & 4 \\
\hline Mean no. of & mean & 1.23 & 1.41 & $0.62^{\mathrm{A}}$ & $1.17^{\mathrm{B}}$ & 0.97 & $0.83^{\mathrm{A}}$ \\
species per & initial & 2.00 & 3.00 & 1.60 & $4.60^{\mathrm{B}}$ & 1.80 & 2.00 \\
sample & final & 0.80 & 1.50 & 0.30 & 0.20 & 1.30 & 1.30 \\
\hline \multirow{2}{*}{ Shannon index of } & mean & 0.63 & 0.68 & 0.78 & 0.96 & 0.29 & 0.61 \\
diversity & initial & 1.69 & 1.72 & 1.92 & 2.30 & 2.06 & 2.13 \\
& final & 0.00 & 0.25 & 0.00 & 0.69 & 0.03 & 0.08 \\
\hline
\end{tabular}

Significant differences $(\mathrm{P}<0.05):^{\mathrm{A}}=$ between compost variants $\mathrm{C}$ and $\mathrm{A}$ or $\mathrm{C}$ and $\mathrm{S} ;{ }^{\mathrm{B}}=$ between litter thickness variants $\mathrm{C}_{1}$ and $\mathrm{C}_{2}, \mathrm{~A}_{1}$ and $\mathrm{A}_{2}$, or $\mathrm{S}_{1}$ and $\mathrm{S}_{2} ;{ }^{\mathrm{C}}=$ between initial and final values.

In the first month of the investigation a decrease in the abundance of oribatid mites was noted in all the experimental treatments - on average by about $40 \%$. In compost with wood-ash, their abundance was stabilized during the next months at a low level (160-3250 ind. $/ \mathrm{m}^{2}$, Fig. 1). By contrast, in compost alone - after the above-mentioned decrease - the abundance of oribatid mites started to increase gradually from the 3rd month and its maximum was in the 10th month (102 000-116 000 ind. $/ \mathrm{m}^{2}$ ), but by the 12th month it decreased to $9910-17710 \mathrm{ind} . / \mathrm{m}^{2}$. In compost with straw, the abundance of oribatid mites increased distinctly in the 10th month $\left(\mathrm{S}_{1}\right)$ or in 12th month $\left(\mathrm{S}_{2}\right)$.

In total, 26 species of oribatid mites were recorded. In particular variants of the experiment the number of species of oribatid mites ranged from 13 to 20 during 


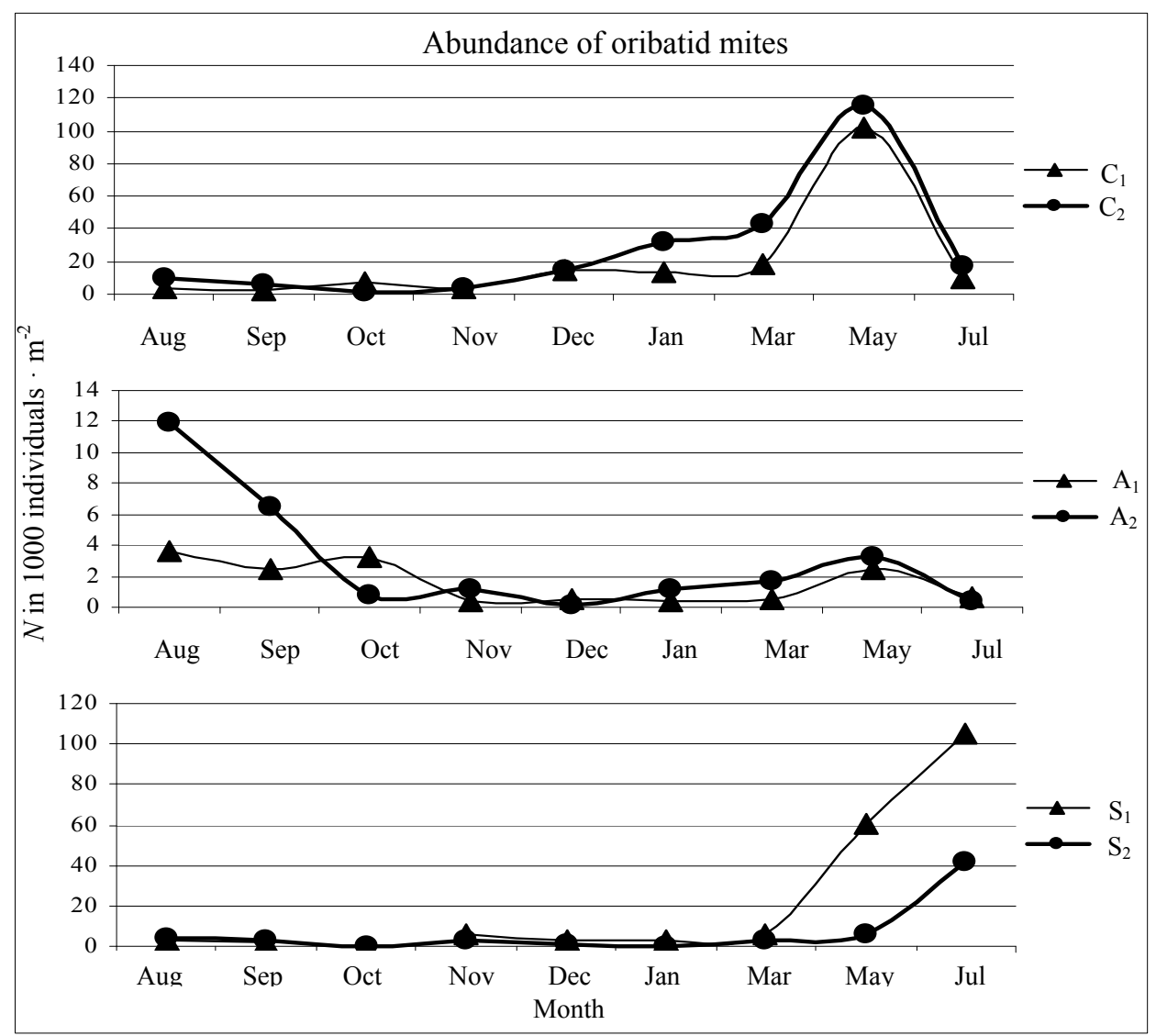

Fig. 1. Changes in abundance of oribatid mites in investigated compost variants

the whole experiment. However, at the beginning of the experiment species number ranged from 9 to 16 , and at the end it was distinctly lower (1-5).

In the whole experiment, the mean number of species per sample was low, and -depending on treatment - varied from 0.62 to 1.41 . The lowest value was noted in $\mathrm{A}_{1}$, and differences between $\mathrm{C}_{1}$ and $\mathrm{A}_{1}$ were statistically significant. In the first month of the research, species number per sample was relatively high (1.6-4.6), but at the end of the experiment it decreased in all kinds of substrates, and exceptionally low values (0.2-0.3) were noted in treatments with wood-ash.

A similar decreasing trend was observed in the case of the Shannon index of species diversity $\left(H^{\prime}\right)$. It was high at the beginning of the experiment, and considerably lower at the end. In spite of the decrease in species diversity of oribatid mites, which was noted in all the treatments during the experiment, the increase in their abundance in variants $\mathrm{C}$ and $\mathrm{S}$ seems to be encouraging. 
At the beginning of the experiment, the dominance structure and hierarchy of species in all treatments were similar to those found in soils of Scots pine forests. Except one variant $\left(\mathrm{S}_{2}\right)$, Oribatula tibialis (Nicolet, 1855) was mostly predominant (Table 3). Other relatively frequent species included Chamobates cuspidatiformis Trägårdh, 1904, Metabelba pulverulenta C. L. Koch, 1839, Tectocepheus velatus Michael, 1880, Heminothrus peltifer (C. L. Koch, 1839), Suctobelba sp., and Oppiella nova (Oudemans, 1902).

At the end of the 12-month experiment, a considerable decrease in abundance of most species was noted. The only exception was Ramusella mihelcici (Pérez-Ínigo, 1965). This species mostly strongly influenced the total number of species. Its population included mostly mature stages (imagines), which constituted $97 \%$ of all individuals.

Table 3. Abundance of selected Oribatid mites (no. of individuals, $10^{3} \cdot \mathrm{m}^{-2}$ ) in sewage sludge composts $(\mathrm{C}=$ compost alone, $\mathrm{A}=$ with wood-ash, $\mathrm{S}=$ with straw $)$ mixed with 1 or $2 \mathrm{~cm}$ of leaf litter

\begin{tabular}{|c|c|c|c|c|c|c|c|}
\hline \multirow{2}{*}{ Species } & & \multicolumn{6}{|c|}{ Experimental variants } \\
\hline & & \multirow{2}{*}{$\begin{array}{c}\mathrm{C}_{1} \\
0.13\end{array}$} & \multirow{2}{*}{$\begin{array}{c}\mathrm{C}_{2} \\
0.42\end{array}$} & \multirow{2}{*}{$\begin{array}{c}\mathrm{A}_{1} \\
0.04\end{array}$} & \multirow{2}{*}{$\begin{array}{c}\mathrm{A}_{2} \\
0.14\end{array}$} & \multirow{2}{*}{$\begin{array}{l}\mathrm{S}_{1} \\
0.04\end{array}$} & \multirow{2}{*}{$\begin{array}{r}\mathrm{S}_{2} \\
0.20\end{array}$} \\
\hline Chamobates & mean & & & & & & \\
\hline cuspidatiformis & initial & 0.81 & 2.60 & 0.33 & $1.30^{\mathrm{B}}$ & 0.16 & $1.46^{\mathrm{B}}$ \\
\hline (Trägårdh) & final & & $0.16^{\mathrm{C}}$ & & & & \\
\hline Metabelba & mean & 0.09 & 0.11 & 0.11 & 0.11 & 0.18 & 0.05 \\
\hline $\begin{array}{l}\text { pulverulenta } \\
\text { C. L. Koch }\end{array}$ & first & & 0.16 & 0.16 & 0.65 & 0.16 & 0.33 \\
\hline \multirow{3}{*}{$\begin{array}{l}\text { Oppiella nova } \\
\text { (Oudemans) }\end{array}$} & mean & 0.05 & 0.11 & 0.04 & 0.09 & 0.13 & 0.07 \\
\hline & initial & 0.16 & 0.16 & 0.16 & 0.16 & 0.16 & 0.33 \\
\hline & final & & 0.33 & & 0.16 & 0.16 & 0.16 \\
\hline \multirow{2}{*}{$\begin{array}{l}\text { Oribatula tibialis } \\
\text { (Nicolet) }\end{array}$} & mean & 0.60 & 0.87 & 0.36 & 0.63 & 0.25 & 0.25 \\
\hline & initial & 1.79 & $4.71^{\text {B }}$ & 1.63 & $3.25^{\text {в }}$ & 0.98 & $0.49^{\mathrm{A}}$ \\
\hline \multirow{3}{*}{$\begin{array}{l}\text { Ramusella mihelcici } \\
\text { (Perez-Ínigo) }\end{array}$} & mean & 18.06 & $25.12^{\text {B }}$ & $0.72^{\mathrm{A}}$ & $0.72^{\mathrm{A}}$ & 19.95 & $6.07^{\mathrm{AB}}$ \\
\hline & initial & 0.16 & 0.33 & 0.16 & 0.16 & & \\
\hline & final & $9.91^{\mathrm{C}}$ & $16.90^{\mathrm{B}}$ & 0.65 & 0.16 & 104.81 & $41.60^{\mathrm{B}}$ \\
\hline \multirow{2}{*}{$\begin{array}{l}\text { Tectocepheus velatus } \\
\text { (Michael) }\end{array}$} & mean & 0.05 & 0.11 & 0.02 & 0.25 & 0.09 & 0.07 \\
\hline & initial & 0.16 & 0.16 & 0.16 & 0.98 & 0.49 & 0.16 \\
\hline
\end{tabular}

Significant differences $(\mathrm{P}<0.05){ }^{\mathrm{A}}=$ between compost variants $\mathrm{C}$ and $\mathrm{A}$ or $\mathrm{C}$ and $\mathrm{S} ;{ }^{\mathrm{B}}=$ between litter thickness variants $\mathrm{C}_{1}$ and $\mathrm{C}_{2}, \mathrm{~A}_{1}$ and $\mathrm{A}_{2}$, or $\mathrm{S}_{1}$ and $\mathrm{S}_{2} ;{ }^{\mathrm{C}}=$ between initial and final values.

\section{DISCUSSION}

Composted sewage sludge can be used as fertilizer, material for improvement of soil structure, or for land reclamation. The main limitation of the use of sewage sludge is connected with presence of heavy metals, especially lead, cadmium, copper, and zinc (JęDRCZAK \& HAZIAK 2005). 
Compost used in this experiment received positive opinions on the basis of chemical, microbiological, and parasitological analyses from the Institute of Soil Science and Plant Cultivation (IUNG) in Puławy. This compost was permitted for use as fertilizer in some sections of agriculture. This compost can be used also in land reclamation of waste disposal sites and in nonagricultural soils. It was found that this fertilizer poses no sanitary threat, and contains trace concentrations of heavy metals, considerably lower than current Polish standards (KABATA-PENDiAs et al. 1995).

Composting of sewage sludge consists in its transformation into a form that resembles soil in consistency and texture (SIUTA \& WASIAK 2001). Composting eliminates the odor nuisance and presence of pathogenic organisms as well as decreases the content of heavy metals. Sewage sludge should be mixed - during the process of composting - with a structuring material, which provides additional organic matter and secures an optimum $\mathrm{C}: \mathrm{N}$ ratio (about 30:1). Various materials are added to composts in practice, e.g. straw, sawdust, bark, green biomass, brown coal dust, etc. The $\mathrm{C}: \mathrm{N}$ ratio recorded in this experiment was typical for composts produced on the basis of sewage sludge (JĘDRCZAK \& HAZIAK 2005).

Small soil animals perform very significant functions, which determine the fertility of the biotope. Some soil habitats, especially those degraded by human pressure, are characterized by species-poor communities of soil animals. Organic matter decomposition cannot proceed properly in such conditions. Natural succession of mesofauna on these kinds of sites is slow and should be activated by reintroduction (SzUJECKI 1990). Therefore, attempts at soil fauna inoculation are reasonable. In our climatic zone, natural succession is always aimed at a forest ecosystem. Because of this, the collection of material for soil fauna inoculation from a mature Scots pine forest was justifiable.

It is considered that soil animals can be used for land reclamation and remediation, principally in two ways. Firstly, they can take part in the process, increasing the overall, and especially microbial, metabolic activity of the soil. Secondly, soil animals can be used as bioindicators of changes taking place in soil microhabitats (HAIMI 2000).

There are many reports in scientific literature about oribatid mites as bioindicators (KLIMEK 2000). Among soil fauna, saprophages are recognized as especially good bioindicators (ANDREws et al. 1989; BuTOVSKY 1996). The saprophagous oribatid mites are regarded, among others, as useful bioindicators of the degree of decomposition and biological properties of forest humus (SENICZAK 1979) and of the level of industrial pollution (KLIMEK 2000).

Examined kinds of substrate (composts) were enriched by various systematic groups of soil animals taken from litter, and oribatid mites can be regarded as bioindicators of changes taking place in the studied microhabitats.

This laboratory experiment made it possible to observe the abundance dynamics of oribatid mites in a 12-month cycle in relatively stable environmental conditions. We are conscious that these conditions differ from natural conditions, e.g. in the range of temperature and humidity changes, which can affect the seasonal variation of mites in our climatic zone (REEvEs 1967). However, taking samples in winter is hardly possible because of frost penetration of the soil. 
The abundance of oribatid mites noted at the beginning of experiment, after addition of a 1-cm-thick layer of litter, was similar in all treatments stabilized, and twice as high as that noted in a forest nursery in the first year of Scots pine cultivation, after the use of a similar experiment (KLIMEK et al. 2008). In that nursery, the abundance of oribatid mites was increased markedly in the second year of the experiment - on irrigated sites, but in that experiment no impact of fertilization with compost on the abundance of oribatid mites was noted. A similar situation was observed in another experiment, carried out in a forest nursery and on former arable land: the addition of sawdust and bark to the sewage sludge did not influence the abundance of oribatid mites (ROLBIECKI et al. 2007a). By contrast, in the presented experiment, composts distinctly affected the mean abundance of these mites.

Sulkava et al. (2001) in a microcosm experiment, after the use of inoculation of microbes and soil fauna, noted a development of fauna and small changes in the number of species at the beginning and end of the experiment. In our experiment, in the first month of the trial, a considerable decrease in abundance of oribatid mites in all treatments was noted. Next, the abundance started to increase, depending on the kind of substrate. A great increase in the total number of oribatid mites was connected with the development of the Ramusella mihelcici population.

Our results indicate that oribatid mites can be used as bioindicators for testing of different organic fertilization under laboratory conditions.

Acknowledgements: We gratefully acknowledge the company Agromis (owned by Rafał Piasecki) that provided the compost used in these trials. The study was financially supported by the Regional Fund for Research and Implementation of the Kuyavian-Pomeranian Province.

\section{REFERENCES}

Andrews S. M., Cooke J. A., Johnson M. S. 1989. Distribution of trace element pollutants in a contaminated ecosystem established on metalliferous fluorspar tailings. Fluoride Envir. Pollut. 60: $165-179$.

Berthet P., Gerard G. 1965. A statistical study of microdistribution of Oribatei (Acari) I. The distribution pattern. Oikos 16: 214-227.

Butovsky R. O. 1996. Insects in bioindication of soil pollution. In: Bioindicator System for Soil Pollution (van Straalen N. M., Krivolutsky A. D. Eds), pp. 155-163, Kluwer Academic Publisher, Dordrecht.

Haimi J. 2000. Decomposer animals and bioremediation of soils. Environ. Pollut. 107: 233-238.

Hanlon R. D. G., ANDERson J. M. 1980. The influence of macroarthropod feeding activities on microflora in decomposing leaf litter. Soil Biol. Biochem. 12: 255-261.

HANLON R. D. G., ANDERson J. M. 1979. The effects of Collembola grazing on microbial activity in decomposing leaf litter. Oecologia 38: 93-99

Hunta V. 2007. The role of soil fauna in ecosystems: A historical review. Pedobiologia 50: 489495.

JęDRCZAK A., HAZIAK K. 2005. Określenie wymagań dla kompostowania i innych metod biologicznego przetwarzania odpadów [Assessment of needs for composting and other methods of biological waste processing]. Pracownie Badawczo-Projektowe EKOSYSTEM Sp. z o.o., Zielona Góra (in Polish). 
Kabata-Pendias A., Piotrowska M., Motowicka-Terelak T., Maliszewska-Kordybach B., Filipiak K., Krakowiak A., Pietruch C. 1995. Podstawy chemicznego zanieczyszczenia gleb [Bases of chemical contamination of soils]. Metale ciężkie, siarka i WWA. Biblioteka Ochrony Środowiska, Warszawa (in Polish).

KLIMEK A. 2000. Wpływ zanieczyszczeń emitowanych przez wybrane zakłady przemysłowe na roztocze (Acari) glebowe młodników sosnowych, ze szczególnym uwzględnieniem mechowców (Oribatida) [Impact of pollutants emitted by factories selected on the young Scots pine forests soil mites (Acari), Oribatida in particular]. Wyd. Uczln. ATR w Bydgoszczy, Rozprawy 99: 1-93 (in Polish).

Klimek A., Rolbiecki S., Rolbiecki R., Hilszczańska D., Malczyk P. 2008. Impact of chosen bare root nursery practices in Scots pine seedling quality and soil mites (Acari). Pol. J. Environ. Stud., 17: 247-255.

LussenHOP J. 1992. Mechanisms of microarthropod-microbial interactions in soil. Adv. Ecol. Res. 23: $1-33$.

LussenHop J., WickLow D. T. 1984. Changes in spatial distribution of fungal propagules associated with invertebrate activity in soil. Soil Biol. Biochem. 16: 601-604.

MagurRan A. E. 1988. Ecological diversity and its measurement. Chapman \& Hall.

Mazur S., Tracz H., 1996. O znaczeniu i sposobach zoo- i fitomelioracji zalesianych gruntów porolnych [On the value and ways of zoomelioration and phytomelioration of afforested postarable grounds]. Post. Techn. Leśn. 60: 26-31 (in Polish).

ReEves R. M. 1967. Seasonal distribution of some forests soil Oribatei. In: Proceeding of the 2nd International Congress of Acarology, pp. 23-30, Akademiai Kiado, Budapest.

Rolbiecki R., Podsiadło C., Klimek A., Rolbiecki S. 2007a. Influence of microirrigation and organic fertilization on the growth of Scots pine (Pinus sylvestris L.) seedlings and the occurrence of soil mites in a post-arable land of two different sylvan-natural regions. Infrastructure and Ecology of Rural Areas 3: 187-195.

Rolbiecki R., Podsiadeo C., Klimek A., Rolbiecki S. 2007b. Preliminary study on the influence of organic fertilization and mulching on the growth of one-year old Scots pine (Pinus sylvestris L.) seedlings and occurrence of soil mites under micro-sprinkler irrigation in two different sylvan-natural regions of Poland. Infrastructure and Ecology of Rural Areas 3: 131-140.

Schneider K., Renker C., Maraun M., 2005. Oribatid mite (Acari, Oribatida) feeding on ectomycorrhizal fungi. Mycorrhiza 16: 67-72.

Schneider K., RenKer C., Scheu S., Maraun M., 2004. Feeding biology of oribatid mites: a minireview. Phytophaga 14: 247-256

SENICZAK S. 1979. Fauna mechowców (Acari, Oribatei) jako indykator biologicznych właściwości próchnic leśnych [Moss mites (Acari, Oribatei) as indicator of the biological properties of forest humus]. Pr. Kom. Nauk. PTG V/37: 157-166 (in Polish).

SiUTA J., WASIAK G. 2001. Zasady wykorzystania osadów ściekowych na cele nieprzemysłowe [Principles of the use of sewage sludge for non-industrial purposes]. Inż. Ekol. 3: 13-42 (in Polish).

Sulkava P., Huhta V., LaAkso J., Gylén E. R. 2001. Influence of soil fauna and habitat patchiness on plant (Betula pendula) growth and carbon dynamics in a microcosm experiment. Oecologia 129: $133-138$.

SzUJECKI A. 1990. Ekologiczne aspekty odtwarzania ekosystemów leśnych na gruntach porolnych [Ecological aspects of redevelopment of forests ecosystems on old farm land]. Sylwan 134 (03/12): 23-40 (in Polish). 